\title{
An Empirical Study about Catering Theory of Dividends: The Proof from Chinese Stock Market
}

\author{
Xiaoguang $\mathrm{Lu}^{1}$, Yiran $\mathrm{Xi}^{1}$, Diqian $\mathrm{Lu}^{2}$ \\ ${ }^{1}$ Business School, Hohai University, ${ }^{2}$ Kingsway Advisors Shanghai Ltd. (China) \\ bongrui@bbu.edu.cn,980691076@.qq.com,_diqian.lu@,botmail.com
}

\begin{abstract}
:
Purpose: This paper aims to study the remarkable effect of dividends catering in Chinese stock market, and its significance on dividend policy and investment decisions. Is there a significant difference in operation status of companies between issuing cash dividend and those without cash dividend, and which one is the better? Is there a significant difference in income level of stocks between issuing cash dividend and those without cash dividend, which one is the higher? Is the irrational preference of cash dividend detracting along with the development and improvement of securities market? All issues above need the market inspection.
\end{abstract}

Design/methodology/approach: Based on related dividend theories and the empirical data of Chinese securities market, we construct three portfolios including stock dividend, cash dividend and non-dividend. The paper studies the returns from these three kinds of portfolios which is analyzed by the least significant difference method, co-integration model, Sharpe index model, and error correction model, and then finally comes to the conclusions.

Findings: The main finding is that there is significant effect of dividends catering in Chinese stock market; the income level of cash dividend portfolio is significantly lower than that of other portfolios; the listed companies issuing stock dividend have a high investment value.

Originality/value: Through collecting a lot of data from the year 2004 to 2009 and developing models to analyze, the paper deem that whether the earnings growth or not 
determines the dividend policy of listed companies, and that stock dividend is the natural choice for those listed companies which have sustainable development advantages.

Keywords: dividend policy, catering theory of dividends, stock dividend, least significant difference method, sharpe index model, co-integration, error correction model

\section{Introduction}

Dividend is a payment made by a corporation to its shareholders. Generally, according to their financial situations and development needs, the listed companies make decisions about whether to issue dividends, in what way and what amount to pay. The decision of dividend is one of the many significant financial decisions of joint-stock companies, which is called 'dividend policy'. Dividend policy studies not only the ratio between companies' retained earnings and ordinary shares dividend payments, but also the dividend payment. Ordinary dividend payments include cash dividend, stock dividend, stock repurchase and stock split. Stock repurchase means that through reacquiring its own stocks, listed companies distribute profits to their shareholders. Stock split represents that through splitting the stock shares, listed companies increase the number of shares without decreasing the total shareholders' equity. Thus, it decreases the stock exchange price and improves the market liquidity. But stock repurchase and stock split are not implement in Chinese securities market. So cash dividend and stock dividend are two basis dividend payments of listed companies. Based on the market performance of Chinese listed companies, this paper classifies dividend policy into cash dividend, stock dividend and non-dividend.

Research by Fisher Black (1976) presented that paying dividend is an extremely delicate work, just like playing an extremely difficult jigsaw puzzle game. All the time, people cannot put its every part together to see its truth face. Research by Brealey and Myers (2002) regarded this research as one of ten unsolved financial problems, and difficult research work are waiting for people to complete.

Research by Lintner (1956) showed that listed companies always used the past dividend policy as a datum point, and they did not want to decrease dividend in general occasions. Then it got the conclusion that company managers have an appropriate dividend payout ratio, and also had the dividend partial adjustment model. This model acted as a basis empirical model which provided a fundamental theoretical framework and the measurement model for this scientific research. Research by Long (1978) showed the catering theory of dividends. It indicated that investors for reaction of listed companies issuing cash dividend and stock dividend was different. Stock issuing cash dividend usually gained more support, while the market response 
of stock issuing stock dividend was relatively passive. As long as the company had the ability of issuing cash dividend, it would cater to investors' preference to issue cash dividend.

According to the disappearing dividends in the securities market and the unpopularity of companies with maintaining cash dividend, research by Baker and Wurgler (2004a, 2004b, 2006) putted forward the catering theory of dividends. It holds that the need of cash dividend by the investors leads to price fluctuations. Premium dividend came from the stock price and the issuance of cash dividend, and affected the choice of company's dividend policy. When the companies decide the dividend policy, they tend to meet the investor's demand. If the investors prefer cash dividend, the listed company will issue cash dividend; if not, the listed company will stop it. Therefore, the change of dividend policy reflects the change of investors' preference; the company adjusts the dividend policy to cater to investor's demand. Through the development process of catering theory of dividends, the preference for cash dividend took great advantage in the last century. Since this century, the proportion of all kinds of fund and other professional investors has been increasing, and the stock market has been more mature. Meanwhile, instead of preference for cash dividend, the preference for stock dividend plays an important role. As the market tending to be relatively rational, it gradually recognizes that the stock dividend reflects the attributes of listed companies' performance.

Is there a significant difference in operation status of companies between issuing stock dividend and those without stock dividend, and which one is the better? Is there a significant difference in income level of stocks between issuing stock dividend and those without stock dividend, which one is the higher? Is the irrational preference for cash dividend detracting along with the development and improvement of securities market? These series of problems all need market inspection. Therefore, this is what the current study aims to investigate.

Based on the detailed research of foreign literature, this paper puts forward the hypothesis that the listed companies with stock dividend have a good investment value. According to empirical data of listed companies in Shanghai Stock Exchange and Shenzhen Stock Exchange, this paper categories these companies into three samples by their dividend policies including stock dividend, cash dividend and non-dividend. Then we make empirical study with cointegration model, Sharpe index model, and error correction model.

The main contribution of this paper is the conclusions from the falsifiability empirical study: there is a significant dividends catering in Chinese stock market; the income level of cash dividend portfolios is obviously lower than that of those with stock dividend and non-dividend; the listed companies issuing stock dividend have high investment value for its ideal operation status; stock investment income fluctuates around its basic value; the growth of listed companies decides the choice of dividend policy. Stock dividend is the natural choice of strong companies. 


\section{Hypotheses and Empirical Design}

The companies which issue stock dividend, cash dividend and non-dividend are all in the same stock market. But the stock returns from different dividend portfolios are different. The dividend policy depends on the operating status, profitability level, the stage of development, income rate and so on. Different policies can reflect the difference of their companies operating situation. What's more, there are significant co-integration relationships between the stock returns from different dividend policies and market risk premium. Therefore, to begin with, we can use the least significant difference method to test whether there are significant differences between stock returns from different dividend policy portfolios. Then we can establish the longterm equilibrium measurement model between market risk premium and stock returns from three different dividend policies. This model can reflect dividend policies' sensitivity to market risk premium and the excess earnings of three kinds of portfolios. Finally, we can also build error correction model to reflect short-term volatility and self-correcting features of three different stock returns around the market risk premium. Thus, we can conclude the hypothesis: Stock returns from different dividend policies have significant differences in the characteristic of long-term equilibrium and that of short-term volatility. So we also get five deductions: listed companies with different dividend policies have significant differences in the $t$ test of least significant difference method; listed companies with different dividend policies have significant difference in the coefficient $\beta$ of sharp index model; listed companies with different dividend policies have significant differences in the coefficient a of sharp index model; listed companies with different dividend policies have significant differences in the coefficient $Y$ of error correction model; listed companies with different dividend policies have significant differences in the coefficient $\lambda$ of error correction model.

Research by Johansen $(1992,1995)$ proposed multiple co-integration vector test method, which was based on maximum likelihood estimation method, namely Johansen co-integration test method. We adopt this method to test the co-integration relationship between the three different stock returns and the market portfolio returns. It also avoids the pseudo regression to lay the foundation for the long-term equilibrium model and error correction model.

The long-term equilibrium model of three different stock returns to the market portfolio returns is constructed with the sharp single index model, which is proposed by William Sharpe (1963). Based on the former model, we construct the error correction model of three different stock returns to the market portfolio returns. Through the elastic level (the coefficient $\gamma$ to reflect) and the modified strength (the coefficient $\lambda$ to reflect), we study the differences among the three stock returns.

This paper takes the normal listed companies from non-financial sectors of China as the research entity. After eliminating financial, ST and *ST classes, it regards all the A shares of 
the China Shanghai stock exchange and Shenzhen stock exchange as the sample space. The time span of the samples starts from December 31, 2004 to December 31, 2009.

According to the stock portfolios of three different dividend policies, we separately calculate their comprehensive indexes of the stock price, which refer to the dividend index. It can reflect general changes of three kinds of price levels: IS, IC and IN. IS represents the composite price index of stock dividend portfolios; IC represents the composite price index of cash dividend portfolios; IN represents the composite price index of non-dividend portfolios. Eliminating the financial stocks, we obtain our sample stocks to calculate the CSI 300 Non-Financial Index, which is recorded as $I_{300}$. Based on the three dividend indexes, we use the first-order logarithmic difference of the dividend index to calculate the time series data of different dividend policy portfolios' comprehensive return on investment, respectively. $\mathrm{R}_{\mathrm{IS}}$ means investment portfolio returns from stock dividend; $\mathrm{R}_{\mathrm{IC}}$ means investment portfolio returns from cash dividend; $\mathrm{R}_{\mathrm{IN}}$ means investment portfolio returns from non-dividend. Meanwhile, we adopt the same method to obtain Shanghai and Shenzhen 300 non-financial index. And its result is recorded as $\mathrm{R}_{300}$. Taking investment portfolio returns $\mathrm{R}_{\mathrm{IS}}$ for example; we get the sharp single index model:

$$
R_{I S, t}=\alpha+\beta R_{m, t}+\varepsilon_{t}
$$

In Formula (1), $R_{m}$ refers to the market investment portfolio returns, which adopt the returns from Shanghai and Shenzhen 300 non-financial index $R_{300}$. $\varepsilon_{t}$ represents residual term, which obeys the normal distribution with zero of mathematical expectation and $\sigma_{\varepsilon}^{2}$ of variance. a symbolizes the intercept of sharp single index model, which reflects the unsystematic risk premium of asset portfolios or securities. If the number of $a$ is distinctively positive, the asset portfolios or securities will have excess earnings. $\beta$ stands for the slope of sharp single index model, which indicates the elasticity of asset portfolios or securities to the market investment portfolio returns.

This empirical study employs the sharp single index model. Based on the market investment portfolio returns, we construct the long-term equilibrium models of $R_{I S}, R_{I C}$ and $R_{I N}$. The data may reflect the elasticity of the different stock portfolios to the market investment portfolio returns and the characteristics and differences of their excess earnings.

Research by Congjun (2012) proposed that the error correction model was the econometric model which had a particular form. According to Engel-Granger theorem proposed by Engle and Granger (1987), if the co-integration relationship exists in a set of variables, their shortterm non-equilibrium relationship will always has an error correction model, which means that the co-integration regression always can be converted to the error correction model. Taking $\mathrm{R}_{\mathrm{IS}}$ 
for example, the error correction model of stock dividend portfolio is:

$$
\Delta R_{I S, t}=c+\gamma \Delta R_{m, t}+\lambda e c m_{t-1}+e_{t}
$$

In Formula (2), $e_{t}$ refers to the residual term of the error correction model. $c$ means the intercept of the model. $\Delta R_{m}$ represents the first-order difference of the market investment portfolio returns, reflecting its growth. $\gamma$ stands for the regression coefficient of the increment of market portfolios returns $\Delta R_{m}$. ecm $\mathrm{c}_{t-1}$ symbolizes the error correction term; $\lambda$ means the slope of the error correction model, suggesting the negative feedback attribute of the system. If co-integration relationship exists among variables and long-term equilibrium property is established, the error coefficient is negative.

Based on the sharp single index model of $R_{I S}, R_{I C}$ and $R_{I N}$, this empirical study constructs the error correction model to reflect the characteristics of the short-term fluctuation and those of error correction. We use the results to study the characteristics and differences of the three different policy portfolio returns.

The following empirical analysis starts from a twofold view: stock investment portfolio returns and sharp single index model.

\section{The Empirical Study}

According to three dividend indexes, this empirical study separately calculates the comprehensive stock returns from three different dividend policies: $R_{I S}, R_{I C}$ and $R_{I N}$, with the first-order logarithmic difference method. The different investment income directly reflects the operating status and market performance of listed companies with different dividend policies. Table 1 is the statistics including mean, standard deviation and dispersion coefficient of $R_{I S}, R_{I C}$ and $\mathrm{R}_{\mathrm{IN}}$.

\begin{tabular}{|l|l|l|l|}
\hline statistics & $\mathbf{R}_{\mathbf{I S}}$ & $\mathbf{R}_{\mathbf{I C}}$ & $\mathbf{R}_{\mathbf{I N}}$ \\
\hline mean & 0.001435 & 0.000941 & 0.000998 \\
\hline standard & 0.022907 & 0.021649 & 0.021930 \\
\hline dispersion coefficient & 15.963066 & 23.006376 & 21.973948 \\
\hline
\end{tabular}

Table 1. The statistical description of the stock returns from three dividend policies

Among the mean of the stock returns from three dividend policies, the mean level of the stock returns from stock dividend portfolio $\left(R_{I S}\right)$ is 0.001435 , which is significantly higher than that from cash dividend portfolio $\left(R_{I C}\right)$ and that from non-dividend portfolio $\left(R_{I N}\right)$; at the same time, 
the differences between $\mathrm{R}_{\mathrm{IC}}$ and $\mathrm{R}_{\mathrm{IN}}$ is very small. The results indicate that the operating status and market performance of the listed companies issuing stock dividend are better than that of the companies issuing cash dividend and non-dividend companies.

Analyzing the dispersion coefficient of stock returns from three stock dividend policies, we can see that the dispersion coefficient of stock dividend portfolio $\left(R_{I S}\right)$ is obviously lower than that of cash dividend portfolio $\left(R_{I C}\right)$ and that of non-dividend portfolio $\left(R_{I N}\right)$; what's more, there is a slightly differences between $R_{I C}$ and $R_{I N}$. The consequences show that the stock returns from stock dividend portfolio ( $\mathrm{R}_{\mathrm{IS}}$ ) not only has a high mean level, but also has a small dispersion degree. Furthermore, it indicates that the operating status and market performance of listed companies issuing stock dividend policy are better than those of the other kinds of listed companies.

In order to get the result of differences among the stock returns from three dividend policies, three different dividend policy portfolios ( $R_{I S}, R_{I C}$ and $\left.R_{I N}\right)$ are formed three test groups. Using the least significant difference method to test the mean differences of every group to see whether there are significant differences between them. Table 2 is the results of $t$ test.

\begin{tabular}{|l|l|l|l|}
\hline \multicolumn{2}{|l|}{$t$ test group } & \multicolumn{1}{|c|}{ mean difference } & \multicolumn{1}{c|}{ T test(Prob.) } \\
\hline the first group & $\mathbf{R}_{\mathrm{IS}}-\mathbf{R}_{\mathrm{IC}}$ & 0.000495 & $2.218575(0.026700)$ \\
\hline the second group & $\mathbf{R}_{\mathrm{IS}}-\mathbf{R}_{\mathrm{IN}}$ & 0.000437 & $1.557053(0.119719)$ \\
\hline the third group & $\mathbf{R}_{\mathrm{IC}}-\mathbf{R}_{\mathrm{IN}}$ & -0.000058 & $-0.266652(0.789783)$ \\
\hline
\end{tabular}

Table 2. The t test of stock returns from three dividend policies

In the first group of $\mathrm{R}_{\mathrm{IS}}-\mathrm{R}_{\mathrm{IC}}$, the mean difference between the stock returns from stock dividend portfolio $\left(R_{I S}\right)$ and that from cash dividend portfolio $\left(R_{I C}\right)$ is 0.000495 . What's more, the $p$ value of $t$ tests in the first groups is 0.026700 , which belongs to the small probability event. It has the refusal of null hypothesis that the differences between different dividend policy portfolios are zero. Thus, the return of stock dividend portfolio is significantly higher than that of cash dividend portfolio.

Therefore, the stock returns from listed companies with different dividend policies exists significant differences, and the stock returns from the stocks issuing stock dividend policy is obviously higher.

Then using Johansen co-integration test methods, as well as the related algorithms given by MacKinnon, Haug and Michelis (1999), this empirical adopts the dependent variable $\left(\mathrm{R}_{\mathrm{IS}}, \mathrm{R}_{\mathrm{IC}}\right.$, $\mathrm{R}_{\mathrm{IN}}$ and $\mathrm{R}_{300}$ ) of Sharpe index model to make multivariate co-integration analysis. 
In order to meet the need of fitting sharp single index long-term equilibrium model and error correction model, this empirical study makes co-integration analysis of $R_{I S}, R_{I C}$, and $R_{I N}$, with $\mathrm{R}_{300}$ respectively. The results are shown in table 3 .

\begin{tabular}{|c|c|c|}
\hline Hypothesized No. of CE(s) & Trace Statistic(Prob.) & Max-Eigen Statistic(Prob.) \\
\hline \multicolumn{3}{|c|}{$\mathbf{R}_{\mathrm{IS}}$} \\
\hline None & $432.4293(0.0001)$ & $238.0481(0.0001)$ \\
\hline At most 1 & $194.3812(0.0000)$ & $194.3812(0.0000)$ \\
\hline \multicolumn{3}{|c|}{$\mathbf{R}_{\mathbf{I C}}$} \\
\hline None & $427.3153(0.0001)$ & $235.4165(0.0001)$ \\
\hline At most 1 & $191.8988(0.0000)$ & $191.8988(0.0000)$ \\
\hline \multicolumn{3}{|c|}{$\mathbf{R}_{\text {IN }}$} \\
\hline None & $411.3901(0.0001)$ & $222.9402(0.0001)$ \\
\hline At most 1 & $188.4499(0.0000)$ & $188.4499(0.0000)$ \\
\hline
\end{tabular}

Table 3. The co-integration test of CSI300 non-financial index return

In table 3, the results refuse the null hypothesis when the number of co-integration relationship is zero and at most 1 . It shows that the returns on investment of each dividend policy with the returns from Shanghai and Shenzhen 300 non-financial index have significant co-integration relationship. Therefore, we can eliminate pseudo regression problem to meet the need of fitting sharp single index long-term equilibrium model and error correction model.

Based on the co-integration relationship test, according to Formula (1), we adopt $R_{300}$ as the market investment portfolio returns. And then we separately fit the sharp single index longterm equilibrium model of three different policy portfolios. Table 4 shows their regression estimators and test value.

\begin{tabular}{|l|l|l|l|}
\hline \multicolumn{1}{|c|}{ statistics } & \multicolumn{1}{c|}{$\mathbf{R}_{\mathrm{IS}}$} & \multicolumn{1}{c|}{$\mathbf{R}_{\mathrm{IC}}$} & \multicolumn{1}{c|}{$\mathbf{R}_{\mathrm{IN}}$} \\
\hline $\boldsymbol{a}$ (Prob.) & $0.0004(0.0564)$ & $-0.0001(0.4535)$ & $0.0000(0.9897)$ \\
\hline $\boldsymbol{\beta}$ (Prob.) & $1.0135(0.0000)$ & $0.9836(0.0000)$ & $0.9490(0.0000)$ \\
\hline Adjusted R-square & 0.9121 & 0.9619 & 0.8725 \\
\hline F-statistic(Prob.) & $\begin{array}{l}12594.2300 \\
(0.0000)\end{array}$ & $\begin{array}{l}30675.7900 \\
(0.0000)\end{array}$ & $\begin{array}{l}8310.9400 \\
(0.0000)\end{array}$ \\
\hline
\end{tabular}

Table 4. The regression and test value of sharp single index model

In table 4, their $\mathrm{p}$ values (F-statistic) of the sharp single index model are all tending to zero. The minimum value of adjusted R-square is 0.8725 , indicating that three sharp single index models are all significant and have better fitting effect.

In table 4 , their $\mathrm{p}$ values $(\beta)$ of three sharp single index model all tend to zero, indicating that the market investment portfolio returns have significant impact on their investment portfolio 
returns. The system risk premium is the main factor of the change of the investment portfolio returns from the dividend policy. The coefficient $\beta$ of stock dividend portfolio is 1.0135 , which is the highest value and is the only one above 1 among the three dividend policy portfolios. It reflects that the stock dividend portfolio is sensitive to the change of the market investment portfolio returns. Meanwhile, the minimum value is the coefficient $\beta$ value of non-dividend portfolio with 0.9490 ; the coefficient $\beta$ value of cash dividend portfolio is in the intermediate position. However, both the value of cash dividend portfolio and non-dividend portfolio are all less than 1 , suggesting that their dividend policy portfolios is relatively conservative to the change of the market investment portfolio returns.

Only the $t$ test of regression constant a of stock dividend portfolio is at the $5.64 \%$ significant level and positive. The value of cash dividend portfolio and non-dividend portfolio are all not significant, so we cannot refuse the null hypothesis that the overall truth value is zero. Therefore, the excess earnings only exist in the stock dividend portfolios. The excess earnings of cash dividend portfolios and non-dividend portfolios tend to zero, which means they do not have significant excess earnings.

Thus, we can draw some conclusions: the coefficient $\beta$ of sharp single index model among different dividend policy is significant; the coefficient a of that is distinctively different. The regression coefficient of sharp single index model of stock dividend is prominently larger; the coefficient a of that is significant.

From the Co-integration theory, we know that if there is a co-integration relationship, a longterm equilibrium relationship and short-term error correction relationship will exist among variables. Error correction model reflects the inherent law that the trajectory of things development astringes equilibrium level. Its specific performance is the self-adaptive process of closed-loop system under the negative feedback process.

Based on the long-term equilibrium, according to Formula (2), we separately fit the sharp single error correction model of three different policy portfolios. Table 5 shows their regression estimators and test values.

\begin{tabular}{|l|l|l|l|}
\hline \multicolumn{1}{|c|}{ statistics } & \multicolumn{1}{c|}{$\mathbf{R}_{\text {Is }}$} & \multicolumn{1}{c|}{$\mathbf{R}_{\text {IC }}$} & \multicolumn{1}{c|}{$\mathbf{R}_{\text {IN }}$} \\
\hline $\boldsymbol{C}$ (Prob.) & $0.0000(0.9954)$ & $0.0000(0.9962)$ & $0.0000(0.9959)$ \\
\hline$\gamma$ (Prob.) & $0.9946(0.0000)$ & $0.9759(0.0000)$ & $0.9320(0.0000)$ \\
\hline $\boldsymbol{\lambda}$ (Prob.) & $-0.8396(0.0000)$ & $-0.9299(0.0000)$ & $-0.7681(0.0000)$ \\
\hline Adjusted R-square & 0.9542 & 0.9807 & 0.9342 \\
\hline F-statistic(Prob.) & $12632.1900(0.0000)$ & $30782.3900(0.0000)$ & $8607.8860(0.0000)$ \\
\hline
\end{tabular}

Table 5 . The regression and test value of sharp index error correction model 
In table 5 , their $\mathrm{F}$ test values of the error correction model are significant; their $\mathrm{p}$ values are tending to zero; the values of adjusted R-square are all above 0.9, indicating that their goodness of fit are very ideal. Their intercept items $c$ are all not significant. So we cannot reject the null hypothesis.

Their $p$ values $(\gamma)$ are all tend to zero, indicating that their increments of market portfolio returns have great influence on that of the portfolio returns with different dividend policies. The regression coefficient so $\gamma$ if different dividend policy portfolios are all greater than 0.9 and slightly less than 1 . The order of their value size is just as that of regression coefficient $\beta$ of sharp single index model. From big to small, the value is 0.9946 (stock dividend portfolio), 0.9759 (cash dividend portfolio), and 0.9320 (non-dividend portfolio). The regression coefficient $\gamma$ of stock dividend portfolio is higher than that of the other kinds of dividend policy portfolios.

Their $\mathrm{p}$ value $(\lambda)$ are all tend to zero. It means that error correction terms are the vital factors which influence the increment of stock dividend portfolio. More importantly, the data are all negative, reflecting the negative feedback attribute of error correction and meeting the mathematical properties of the system stable convergence. The results further prove that there is an obvious co-integration relationship among variables.

Therefore, it concludes that the coefficient $\gamma$ of different dividend policies is significant, and is distinctively negative.

\section{Conclusions}

With the analysis and significance test of the least significant difference method, sharp single index long-term equilibrium model and error correction model, we come to the following conclusions:

\subsection{The stock returns between different dividend policy portfolios have significant differences}

In the $t$ test of return rate with the least significant difference method, it has the refusal of null hypothesis that the differences between different dividend policy portfolios are zero. Listed companies with different dividend policies have significant differences in their stock returns. And stock returns from stock dividend policy is obviously higher than that from cash dividend and non-dividend policies. 


\subsection{The stock dividend portfolio has obvious excess earnings}

In the sharp single index long-term equilibrium model, the regression constant a of stock dividend portfolio is the only one at the $5.64 \%$ significant level and positive. And that of other dividend policy portfolios are not significant. So we cannot refuse that the null hypothesis is zero. Therefore, in the sharp single index equilibrium model of three different dividend policy portfolios, only stock dividend portfolio has obvious excess earnings.

\subsection{The stock dividend portfolio on the fluctuations of the market portfolio returns is the most sensitive}

The elastic of coefficient $\beta$ of sharp single index long-term equilibrium model of stock dividend portfolio is the highest. Meanwhile, its regression coefficient $\gamma$ is also the largest one. The result shows that whether from the long-term equilibrium or short-term fluctuation perspective, stock dividend portfolio belongs to the more active stock property of listed companies, these companies have higher risk premium than companies with the other dividend policies.

\subsection{Three kinds of dividend policy portfolios all have significant negative feedback attributes}

The regression coefficient $\mathrm{y}$ of sharp single index error correction model of three different dividend policy portfolios are distinctively negative. The result indicates that three kinds of dividend policy portfolios all have the tendency of returning to their inherent fundamental value. The reaction behavior of ordinary investors for different dividend policy may make the market price fluctuate within a certain range in a period of time, but under the negative feedback mechanism, the market price eventually return to its fundamental value. Due to irrational people and the market's incomplete arbitrage, the market price of the stocks and its portfolio will deviate from its inherent fundamental value. However, under the negative feedback mechanism, the basic value is still served as the center as well as the gravity line, and eventually it converges to the fundamental value.

In conclusion, there is a significant dividends catering in Chinese stock market. The preference for cash dividend is a classical irrational behavior. The stock investment income of cash dividend portfolios is significantly low. The stock investment income of stock dividend portfolios has significant advantages. 


\section{References}

Baker, M., \& Wurgler, J. (2004a). A catering theory of dividends. Journal of Finance, 59, 1125-1165. http://dx.doi.org/10.1111/j.1540-6261.2004.00658.x

Baker, M., \& Wurgler, J. (2004b). Appearing and disappearing dividends: the link to catering incentives. Journal of Financial Economics, 73, 271-288.

http://dx.doi.org/10.1016/j.jfineco.2003.08.001

Baker, M., \& Wurgler, J. (2006). Investor sentiment and the cross-section of stock returns. Journal of Finance, 61, 1645-1680. http://dx.doi.org/10.1111/j.1540-6261.2006.00885.x

Black, F. (1976). The Dividend Puzzle. Journal of Portfolio Management, 3, 5-8. http://dx.doi.org/10.3905/jpm.1976.408558

Brealey, R.A., \& Myers, S.C. (2002). Principle of Corporate Finance. Boston, MA.: Irvin/McGraw-Hill.

Congjun, C. (2012). A study of dynamic econometric relationship between urbanization and service industries growth in China. Journal of Industrial Engineering and Management, 6(1), 8-15.

Engle, R.F., \& Granger, C. (1987). Co-integration and error correction representation, estimation and testing. Econometrica, 55, 251-276. http://dx.doi.org/10.2307/1913236

Johansen, S. (1992). Cointegration in Partial Systems and the Efficiency of Single-Equation Analysis. Journal of Econometrics, 52, 389-402. http://dx.doi.org/10.1016/0304-4076(92)90019-N

Johansen, S. (1995). Likelihood-Based Inference in Cointegrated Vector Autoregressive Models. Oxford: Oxford University Press. http://dx.doi.org/10.1093/0198774508.001.0001

Lintner, J. (1956). Distribution of Incomes of Corporations among Dividends, Retained Earnings, and Taxes. American Economic Review, 46, 97-113.

Long, J. (1978). The market valuation of cash dividends: a case to consider. Journal of Financial Economics, 6, 235-264. http://dx.doi.org/10.1016/0304-405X(78)90031-4

Mackinnon, J.G., Haug, A., \& Michelis, L. (1999). Numerical Distribution Functions of Likelihood Ratio Tests for Cointegration. Journal of Applied Econometrics, 14(5), 563-577. http://dx.doi.org/10.1002/(SICI)1099-1255(199909/10)14:5<563: :AID-JAE530>3.0.CO;2-R

Sharpe, W.F. (1963). A simplified model for portfolio analysis. Management Science, 9, 277-293. http://dx.doi.org/10.1287/mnsc.9.2.277

Journal of Industrial Engineering and Management, 2014 (www.jiem.org)

Article's contents are provided on a Attribution-Non Commercial 3.0 Creative commons license. Readers are allowed to copy, distribute and communicate article's contents, provided the author's and Journal of Industrial Engineering and Management's names are included. It must not be used for commercial purposes. To see the complete license contents, please visit 